\title{
Effects of Heterosigma akashiwo (Raphidophyceae) on protist grazers: laboratory experiments with ciliates and heterotrophic dinoflagellates
}

\author{
Jennifer Clough, Suzanne Strom*
}

Shannon Point Marine Center, Western Washington University, 1900 Shannon Point Rd., Anacortes, Washington 98221, USA

\begin{abstract}
Heterosigma akashiwo is a fish-killing raphidophyte capable of forming dense blooms. Since microzooplankton consume a large fraction of coastal phytoplankton production and readily ingest cells in the $H$. akashiwo size range, the formation of such blooms indicates that grazing has been inhibited. Growth rates of 7 cultured protist grazer species were measured in the presence of $2 H$. akashiwo strains. Both strains were toxic to the 3 largest ciliates tested; all experienced higher mortality in the presence of $H$. akashiwo than when starved. Addition of Rhodomonas sp., a highquality prey species for many protists, sometimes ameliorated $H$. akashiwo toxicity but in other instances did not. Two smaller ciliate species and 2 heterotrophic dinoflagellates were either unaffected by $H$. akashiwo or were able to survive and grow on it. For grazers susceptible to the toxicity, higher $H$. akashiwo cell concentrations and older $H$. akashiwo cultures were both associated with higher mortality. No toxicity was associated with filtrate from $H$. akashiwo culture or from the presence of $H$. akashiwo cells that were not ingested, so the toxic effect of this raphidophyte to large ciliates seems to depend on ingestion of the cells. Mortality of large ciliates, often a major component of coastal microzooplankton communities, is likely an important element of $H$. akashiwo's capability to form persistent blooms.
\end{abstract}

KEY WORDS: Microzooplankton · Growth · Ingestion · Toxicity · Raphidophyte Resale or republication not permitted without written consent of the publisher

\section{INTRODUCTION}

Heterosigma akashiwo is a bloom-forming raphidophyte species, typically rare in the plankton but capable of forming dense, persistent aggregations. $H$. akashiwo is distributed globally in euryhaline, coastal environments, and high cell concentrations are often associated with low-salinity sea surface layers (Honjo 1993, Taylor \& Haigh 1993, Hershberger et al. 1997). Blooms of $H$. akashiwo (formerly referred to as Olisthodiscus luteus and Heterosigma carterae; Hara \& Chihara 1987, Throndsen 1996) have caused massive deaths of penned fish in numerous Pacific Rim countries, including the United States, Chile, Japan, Korea and New Zealand (Honjo 1993, Horner et al. 1997, Khan et al. 1997, and references therein). The mechanism of ichthyotoxicity is not well understood (see below), although toxicity level has been related to environmental conditions (salinity, irradiance, temperature) and growth stage (Ono et al. 2000, Haque \& Onoue 2002).

Blooms of Heterosigma akashiwo, or indeed of any phytoplankton species, indicate that removal of phytoplankton by grazers is reduced relative to growth and accumulation rates of phytoplankton cells (Strom 2002). This is an unusual situation in the marine plankton. Rates of zooplankton grazing are often a substantial fraction of phytoplankton growth rates, even in coastal waters, with most of this grazing attributable to microzooplankton (Calbet \& Landry 2004). H. akashiwo, in particular, has the potential to be a good food for protists and other microzooplankton because phytoplankton similar in size and morphology to $H$. akashiwo are eaten readily by numer- 
ous microzooplankton grazers. Reduced population growth rates or mortality of protist grazers in the presence of $H$. akashiwo could partially explain the formation and persistence of $H$. akashiwo blooms. Although there have been several previous studies of $H$. akashiwo effects on heterotrophic protists (Verity \& Stoecker 1982, Nakamura 1998, Kamiyama \& Arima 2001, Jeong et al. 2002, 2003), none have surveyed a range of taxa, and only one (Verity \& Stoecker 1982) was designed so that $H$. akashiwo toxicity could be distinguished from nutritional insufficiency. We studied the effects of $H$. akashiwo on the growth of heterotrophic dinoflagellates and both tintinnid and aloricate ciliates. The species examined are common and seasonally abundant members of temperate coastal plankton communities.

There is no general agreement as to the mode of Heterosigma akashiwo's fish toxicity. Much research has focused on production of reactive oxygen species (ROS) and their role in damaging gill tissue (Yang et al. 1995, Oda et al. 1997, Twiner \& Trick 2000). A second hypothesis is that mucus, produced by either the alga or the fish, clogs the gills and leads to asphyxiation (Nakamura et al. 1998, Oda et al. 1998). Production of brevetoxin-like neurotoxins has been reported for several strains (Khan et al. 1997, Ono et al. 2000, Haque \& Onoue 2002), and there is evidence that an association with bacteria is required for toxicity (CarrasqueroVerde 1999). Recently Twiner et al. (2004) investigated the effect of $H$. akashiwo-derived extracellular organics on cell metabolism, while Marshall et al. (2003) demonstrated a synergism between ROS and free fatty acids in the ichthyotoxicity of the closely related Chattonella marina. In addition to ichthyotoxicity, $H$. akashiwo is thought to have allelopathic effects on certain other phytoplankton species (Pratt 1966). $H$. akashiwo may well have multiple modes of toxicity that affect different types of aquatic organisms in different ways. At present, however, there is no accepted chemical measure of toxin content in this species.

Our approach to assessing Heterosigma akashiwo toxicity was to use the growth response of potential protist grazers as a measure of the toxic effect. The use of biological responses of marine organisms to assay for toxicity has a long history. Here the approach not only reveals any toxic effect regardless of chemical mechanism, but by employing representative members of an important group of phytoplankton consumers, does so in a way that is relevant to understanding $H$. akashiwo bloom dynamics. In designing these experiments, we wished to distinguish between toxicity and nutritional insufficiency. An algal prey species may fail to support the growth of consumers if essential dietary biochemicals are absent; this is distinct from, and has different ecological consequences than, nega- tive effects of a deleterious compound (Jonasdottir et al. 1998, Colin \& Dam 2002).

Our study addressed the question of toxicity versus nutritional insufficiency in 2 ways: (1) In treatments where Heterosigma akashiwo was offered alone, toxicity was defined as a growth rate significantly lower than that in starved controls. Since the energy expended by protists during prey capture is considered incidental to their total energy budget (Fenchel 1987), even a nutritionally insufficient food should not reduce the growth rate further than starvation unless toxicity plays a role. (2) We included treatments in which $H$. akashiwo was mixed with Rhodomonas sp., a high-quality prey species for many protist grazers. If $H$. akashiwo were nutritionally insufficient, its presence in the mixture might reduce growth relative to the Rhodomonas-only control: grazers would eat less of the high-quality prey species because they would also be consuming the nutritionally insufficient $H$. akashiwo. Only if $H$. akashiwo is toxic, however, would the mixed diet lead to protist growth rates lower than those in the starved control. Inclusion of the mixed diet treatment also allowed us to look for a possible amelioration of $H$. akashiwo toxicity by Rhodomonas sp.

We found reductions in growth rate consistent with toxicity for at least 3 of the protist grazers studied. This prompted additional investigation to explore the mechanism and consequences of Heterosigma akashiwo toxicity. Additional questions addressed were: (1) Is toxicity dependent upon $H$. akashiwo concentration? (2) Does H. akashiwo produce a watersoluble toxin that inhibits protist growth? (3) Does toxicity vary with $H$. akashiwo culture age? (4) Does the presence of $H$. akashiwo reduce the rate at which protist grazers ingest other prey?

\section{MATERIALS AND METHODS}

Cultures. Two non-axenic cultures of Heterosigma akashiwo were obtained from the Provasoli-Guillard National Center for the Culture of Marine Phytoplankton (CCMP, Boothbay Harbor, Maine, USA). One culture, CCMP1914 (strain synonyms: NWFSC-504, UWC-10), was isolated from Guemes Channel, Washington, USA $\left(48.315^{\circ} \mathrm{N}, 122.390^{\circ} \mathrm{W}\right)$, the approximate location of most of our protist grazer isolates. The other culture, CCMP452 (strain synonym: Olisth), was isolated from Long Island Sound on the US Atlantic coast (approximately $41.0^{\circ} \mathrm{N}, 73.0^{\circ} \mathrm{W}$ ) and has been used previously in similar experiments (Verity \& Stoecker 1982), when it was known as Olisthodiscus luteus. Growth rates of both strains were similar (data not shown). A third algal culture, Rhodomonas sp., was chosen for use as a control and in mixed diets because 
it is generally a high-quality food for protists, and because its orange phycoerythrin fluorescence allows it to be distinguished from $H$. akashiwo under epifluorescence microscopy. Algae were maintained in $30 \mathrm{psu}$ f/2 medium without added silicate (Guillard \& Ryther 1962), incubated at $15^{\circ} \mathrm{C}$ and $100 \mu \mathrm{mol}$ photons $\mathrm{m}^{-2} \mathrm{~s}^{-1}$ (13:11 h light:dark cycle), and transferred to fresh medium every 7 to $10 \mathrm{~d}$ to maintain exponential growth. We isolated all protist grazers from waters of northern Puget Sound, USA $\left(48.5^{\circ} \mathrm{N}, 122.7^{\circ} \mathrm{W}\right)$, determined appropriate mixed-algal diets in accordance with Strom \& Morello (1998), and maintained them in culture at Shannon Point Marine Center, Washington, USA. Grazers were cultured in a trace metal-enriched 30 psu seawater medium (hereafter 'ciliate medium') in accordance with Gifford (1985) at $12^{\circ} \mathrm{C}$ in dim light (ca. $2 \mu \mathrm{mol}$ photons $\mathrm{m}^{-2} \mathrm{~s}^{-1}$ ).

Samples of algae and pre-starved protists (see below) were preserved in acid Lugol's solution (10\% final concentration) and measured using inverted microscopy. For all but 2 species, maximum lengths and widths of 20 individuals were obtained from digital images (CoolSnap CF camera) and Optimas 6.2.1 image-analysis software. Strombidium sp. SPMC68 and Eutintinnus sp. were both lost from culture before measurements were taken. Six preserved Strombidium sp. remaining from a prior experiment were measured as described above. For Eutintinnus sp., a photograph of known magnification was used to estimate its size.

Effect of Heterosigma akashiwo on protist growth rate. Seven species of protist grazers (Table 1) were tested for their population growth response to the 2 strains of Heterosigma akashiwo. Algal prey were grown in batch culture, then sampled during midexponential phase and counted using a haemocyto-

Table 1. Cell dimensions $(\mu \mathrm{m})$ of protist grazers $( \pm 1 \mathrm{SD})$ used in experiments with Heterosigma akashiwo. Lorica dimensions are given in parentheses for tintinnids. $\mathrm{n}=20$ for all size determinations except Eutintinnus sp. and Strombidium sp. SPMC68 (see text above)

\begin{tabular}{|lcccc|}
\hline Taxon & Genus and species & Strain ID & Length & Width \\
\hline Tintinnid & Coxliella sp. & SPMC82 & $44 \pm 8$ & $27 \pm 3$ \\
& Metacylis sp. & SPMC84 & $\begin{array}{c}34 \pm 7 \\
(612)\end{array}$ & $\begin{array}{c}(40 \pm 4) \\
(42 \pm 12)\end{array}$ \\
& Eutintinnus sp. & SPMC80 & 38 & 15 \\
& & & $(125)$ & $(20)$ \\
Aloricate & Strombidium sp. & SPMC68 & $57 \pm 7$ & $41 \pm 5$ \\
choreotrich & (chloroplast-retaining) & & & \\
& Strombidium sp. & SPMC92 & $40 \pm 2$ & $20 \pm 3$ \\
Dinoflagellate & Amphidinium longum & SPMC98 & $18 \pm 2$ & $9 \pm 1$ \\
& Noctiluca scintillans & SPMC74 & $296 \pm 54$ & $271 \pm 48$ \\
\hline
\end{tabular}

meter. Protist grazers were starved prior to use. Tintinnids were poured through a 10 or $20 \mu \mathrm{m}$ plastic screen (80 $\mu \mathrm{m}$ for Noctiluca scintillans), then resuspended in prey-free ciliate medium. Most of the medium surrounding aloricate choreotrichs was siphoned off through a $10 \mu \mathrm{m}$ screen (reverse concentration) and replaced with prey-free medium. Ciliates were then incubated for $24 \mathrm{~h}$ to allow any remaining ingested food to be digested. Amphidinium longum was too small to be separated physically from its prey, so it was simply not fed for $6 \mathrm{~d}$, during which time most of the prey cells disappeared.

Grazer density was estimated by counting live cells in replicate droplets of known volume under a dissecting microscope; grazers were then added to triplicate polycarbonate bottles (incubation volumes 50 or $100 \mathrm{ml}$, depending on grazer species). Six diet treatments were used: (1) starved (= ciliate medium only); (2) Rhodomonas sp.; (3) Heterosigma akashiwo CCMP452; (4) H. akashiwo CCMP1914; (5) Rhodomonas sp. + H. akashiwo CCMP452, or (6) Rhodomonas sp. + H. akashiwo CCMP1914. H. akashiwo was always supplied at $2 \times 10^{3}$ cells ml $^{-1}$, and Rhodomonas sp. at $1 \times 10^{4}$ cells $\mathrm{ml}^{-1}$ (Table 2). The former species is larger than the latter $(H$. akashiwo CCMP452: $16.1 \times$ $11.6 \mu \mathrm{m}_{i} H$. akashiwo CCMP1914: $14.8 \times 9.7 \mu \mathrm{m}_{\text {; }}$ Rhodomonas sp.: $10.1 \times 5.5 \mu \mathrm{m})$, so the $1: 5 \mathrm{H}$. akashiwo:Rhodomonas $\mathrm{sp}$. ratio by cell number gave approximately equal concentrations by prey volume of each prey type. A concentration of $1 \times 10^{4}$ cells ml $\mathrm{m}^{-1}$ Rhodomonas sp. was previously shown to be well above the concentration at which protist growth rates saturate (Zirbel 2001). Further, $2 \times 10^{3}$ cells ml ${ }^{-1} H$. akashiwo was chosen as a reasonable simulation of the concentration grazers might experience in a bloom, given field observations of $10^{3}$ to $10^{4}$ cells $\mathrm{ml}^{-1}$ at bloom peaks (Taylor \& Haigh 1993, Kamiyama et al. 2000). In this and all subsequent experiments, the bottles were incubated at $12^{\circ} \mathrm{C}$ in the dark, unmixed for 2 to $3 \mathrm{~d}$, with $10 \mathrm{ml}$ samples taken daily and fixed with acid Lugol's solution (10\% final concentration). Each preserved sample was transferred to a $10 \mathrm{ml}$ settling chamber and the protist grazers enumerated using inverted microscopy (transmitted light illumination). Growth rates $\left(\mu\right.$, doublings $\mathrm{d}^{-1}$ ) were then calculated using the formula:

$$
\mu=\left(\ln T_{t}-\ln T_{0}\right) /[t \times \ln (2)]
$$

where $T_{t}=$ protist abundance at time $t$, and $T_{0}=$ protist abundance at $t=0$. 
Table 2. Summary of experimental treatments and initial algal concentrations (cells ml ${ }^{-1}$ ). R.sp. $=$ Rhodomonas sp.; H.a. $=$ Heterosigma akashiwo; $\mathrm{n}=$ number of replicates per treatment; $\mathrm{nd}=$ not determined. Both $H$. akashiwo strains were from the Provasoli Guillard National Center for the Collection of Marine Phytoplankton (CCMP). Initial protist grazer concentrations (cells $\mathrm{ml}^{-1}$ ) shown in parentheses after grazer species names

\begin{tabular}{|c|c|c|c|c|c|}
\hline \multirow[t]{2}{*}{ Expt } & \multirow[t]{2}{*}{ Grazer species } & \multirow[t]{2}{*}{ Treatment } & \multicolumn{2}{|c|}{$\begin{array}{l}\text { Initial algal } \\
\text { concentration }\end{array}$} & \multirow[t]{2}{*}{$\mathrm{n}$} \\
\hline & & & R. sp & H. a & \\
\hline Growth & $\begin{array}{l}\text { Coxliella sp. (8.6), Metacylis sp. (16.2), } \\
\text { Strombidium sp. SPMC68 (5.8), } \\
\text { Eutintinnus sp. (47.0), Amphidinium } \\
\text { longum (196), Strombidium sp. SPMC92 } \\
\text { (10.8), Noctiluca scintillans (0.8) }\end{array}$ & $\begin{array}{l}\text { (i) Starved } \\
\text { (ii) R.sp. } \\
\text { (iii) H.a. CCMP452 } \\
\text { (iv) H.a. CCMP1914 } \\
\text { (v) R.sp. + H.a. CCMP452 } \\
\text { (vi) R.sp. + H.a. CCMP1914 }\end{array}$ & $\begin{array}{c}0 \\
1 \times 10^{4} \\
0 \\
0 \\
1 \times 10^{4} \\
1 \times 10^{4}\end{array}$ & $\begin{aligned} & 0 \\
& 0 \\
2 & \times 10^{3} \\
2 & \times 10^{3} \\
2 & \times 10^{3} \\
2 & \times 10^{3}\end{aligned}$ & 3 \\
\hline $\begin{array}{l}\text { H.a. concen- } \\
\text { tration effect }\end{array}$ & Coxliella sp. (8.0), Metacylis sp. (9.0) & $\begin{array}{l}\text { (i) Starved } \\
\text { (ii) R.sp. } \\
\text { (iii) R.sp. + H.a. CCMP452 } \\
\text { (iv) R.sp. + H.a. CCMP452 } \\
\text { (v) R.sp. + H.a. CCMP452 }\end{array}$ & $\begin{array}{l}\quad 0 \\
1 \times 10^{4} \\
1 \times 10^{4} \\
1 \times 10^{4} \\
1 \times 10^{4}\end{array}$ & $\begin{array}{c}0 \\
0 \\
2 \times 10^{3} \\
4 \times 10^{3} \\
6 \times 10^{3}\end{array}$ & 2 or 3 \\
\hline $\begin{array}{l}\text { H.a. filtrate } \\
\text { effect }\end{array}$ & Metacylis sp. (8.8) & $\begin{array}{l}\text { (i) Starved } \\
\text { (ii) R.sp. } \\
\text { (iii) R.sp. filtrate } \\
\text { (iv) R.sp. filtrate + R.sp. } \\
\text { (v) H.a. CCMP452 filtrate } \\
\text { (vi) H.a. CCMP452 filtrate + R.sp. }\end{array}$ & $\begin{array}{c}0 \\
1 \times 10^{4} \\
0 \\
1 \times 10^{4} \\
0 \\
1 \times 10^{4}\end{array}$ & $\begin{array}{l}0 \\
0 \\
0 \\
0 \\
0 \\
0\end{array}$ & 3 \\
\hline $\begin{array}{l}\text { 'Age of } \\
\text { culture' effect }\end{array}$ & Coxliella sp. (10.0) & $\begin{array}{l}\text { (i) Starved } \\
\text { (ii) H.a. CCMP452 cultures of } 7 \\
\text { different ages: H.a. only } \\
\text { (iii) H.a. CCMP452 cultures of } 7 \\
\text { different ages: H.a. + R.sp. }\end{array}$ & $\begin{array}{c}0 \\
0 \\
1 \times 10^{4}\end{array}$ & $\begin{array}{c}0 \\
2 \times 10^{3} \\
2 \times 10^{3}\end{array}$ & 2 \\
\hline $\begin{array}{l}\text { H.a. effect on } \\
\text { ingestion of } \\
\text { R.sp. }\end{array}$ & $\begin{array}{l}\text { Metacylis sp. (18.0), Amphidinium } \\
\text { longum (nd) }\end{array}$ & $\begin{array}{l}\text { (i) R.sp. } \\
\text { (ii) H.a. CCMP452 } \\
\text { (iii) R.sp. + H.a. CCMP452 }\end{array}$ & $\begin{array}{c}1 \times 10^{4} \\
0 \\
1 \times 10^{4}\end{array}$ & $\begin{array}{c}0 \\
2 \times 10^{3} \\
2 \times 10^{3}\end{array}$ & 3 \\
\hline
\end{tabular}

We did not measure feeding rates during growth experiments, but did examine grazers to see whether they had ingested Heterosigma akashiwo. To this end, additional $10 \mathrm{ml}$ samples were taken before the incubation period began and again 0.5 to $24 \mathrm{~h}$ later, depending on the presumed grazing rate of the grazer being tested. These samples were preserved with $10 \%$ glutaraldehyde $(0.5 \%$ final concentration) and stained with 4,6-diamidino-2-phenylindole (DAPI). The samples were refrigerated in the dark for $24 \mathrm{~h}$, then filtered in their entirety onto $25 \mathrm{~mm}$ diameter polycarbonate membranes with pore size 0.8 to $8.0 \mu \mathrm{m}$, depending on grazer size. The filters were mounted on slides with immersion oil and frozen at $-20^{\circ} \mathrm{C}$ until they could be observed with epifluorescent microscopy. Under blue light excitation, $H$. akashiwo cells fluoresce red, while Rhodomonas sp. cells fluoresce orange. A minimum of 100 cells was examined per slide or, if fewer than 100 cells were present, all cells were examined. A grazer population was considered to have ingested $H$. akashiwo if at least 5 grazers were observed to contain at least $1 \mathrm{H}$. akashiwo cell each on at least 1 slide. Because Amphidinium longum feeds by myzocytosis, intact cells are not ingested. For this grazer species we looked for red-fluorescing food vacuoles. The large Strombidium sp. retained chloroplasts from ingested prey, masking the fluorescence of ingested prey cells in food vacuoles. For this species, we confirmed feeding on $H$. akashiwo by making behavioral observations under a dissecting microscope.

The experiment with Noctiluca scintillans required modification because $N$. scintillans grows more slowly than the other grazers, is more resistant to starvation, and achieves lower densities in culture. For this experiment, the pre-experiment starvation period was $7 \mathrm{~d}$ and the subsequent growth experiment lasted $22 \mathrm{~d}$. Algal prey were counted using a Palmer-Maloney chamber on Days 3, 7, and 15, and algae were added as needed to restore initial concentrations (Table 2). Total incubation volume was $300 \mathrm{ml}$; samples of $50 \mathrm{ml}$ each were taken on Days 0, 3, 7, 10, 15 and 22. Each sample was sieved through a $40 \mu \mathrm{m}$ screen and backrinsed into approximately $10 \mathrm{ml}$ seawater, then preserved with acid Lugol's solution (10\% final concentration). Inverted microscope counts and growth rate calculations were performed as described above.

Heterosigma akashiwo concentration gradient effect on tintinnid abundance. Two experiments were 
conducted to determine whether varying the concentration of Heterosigma akashiwo in mixed-algal treatments affected ciliate abundance. The tintinnids Coxliella sp. and Metacylis sp. were tested because, in growth rate experiments, both showed a marked decrease in growth rate in the presence of $H$. akashiwo. Preparations for the experiments (growth of stock cultures, pre-starvation of tintinnids) were as described above. In all treatments, the concentration of Rhodomonas sp. was $1 \times 10^{4}$ cells ml ${ }^{-1}$ and $H$. akashiwo strain CCMP452 was used. In the Coxliella sp. experiment, approximately 8 grazers $\mathrm{ml}^{-1}$ (final concentration) were added to duplicate bottles containing the following treatments: (1) starved (= ciliate medium only); (2) Rhodomonas sp.; (3) Rhodomonas sp. $+2 \times$ $10^{3}$ cells ml $\mathrm{m}^{-1} H$. akashiwo, (4) Rhodomonas sp. $+4 \times$ $10^{3}$ cells ml ${ }^{-1} H$. akashiwo, and (5) Rhodomonas sp. + $6 \times 10^{3}$ cells $\mathrm{ml}^{-1} H$. akashiwo. Incubation volume in the experimental bottles was $30 \mathrm{ml}$. For the Metacylis sp. experiment, the procedure was the same except that bottles were run in triplicate, initial grazer concentration was 9 grazers $\mathrm{ml}^{-1}$, incubation volume was $100 \mathrm{ml}$, and the $H$. akashiwo addition levels were $1 \times$ $10^{2}, 5 \times 10^{2}, 1 \times 10^{3}$ and $2 \times 10^{3}$ cells ml ${ }^{-1}$ (Table 2 ). Feeding was not examined in these experiments.

Effect of Heterosigma akashiwo filtrate on Metacylis sp. abundance. An experiment was performed to determine whether Heterosigma akashiwo toxicity was due to dissolved substances exuded by the algae. Cell-free filtrate from Rhodomonas sp. and $H$. akashiwo CCMP452 was prepared by filtering approximately $100 \mathrm{ml}$ of dense algal culture (initial concentrations of $8.23 \times 10^{5}$ cells ml ${ }^{-1}$ Rhodomonas sp., $1.84 \times 10^{5}$ cells $\mathrm{ml}^{-1} H$. akashiwo) through a $5 \mu \mathrm{m}$ pore-size polycarbonate filter overlain on a $0.7 \mu \mathrm{m}$ effective pore-size glass fiber filter using gentle $(<125 \mathrm{~mm} \mathrm{Hg})$ vacuum pressure. The filtrates were then used to set up triplicate bottles of the following treatments: (1) starved (= ciliate medium only); (2) Rhodomonas sp.; (3) 10\% (final volume) Rhodomonas sp. filtrate (equivalent to $8.23 \times 10^{4}$ cells ml ${ }^{-1}$ ); (4) $10 \%$ Rhodomonas sp. filtrate + Rhodomonas sp; (5) $10 \% H$. akashiwo filtrate (equivalent to $1.84 \times 10^{4}$ cells ml ${ }^{-1}$ ); and (6) $10 \%$ H. akashiwo filtrate + Rhodomonas sp. Initial Rhodomonas sp. concentrations were always $1 \times 10^{4}$ cells $\mathrm{ml}^{-1}$, while initial Metacylis sp. concentration was 9 cells $\mathrm{ml}^{-1}$ in an incubation volume of $100 \mathrm{ml}$ (Table 2).

'Age of culture' effect on Coxliella sp. growth rate. Observations made during our study indicated that the age of the Heterosigma akashiwo culture used to supply prey cells might affect ciliate growth rate. To test this hypothesis, we generated a series of duplicate $H$. akashiwo CCMP452 cultures of varying ages (hereafter 'experimental cultures') to use in a Coxliella sp. growth experiment. Two different 'parent cultures' were started $6 \mathrm{~d}$ before the first experimental cultures were initiated. These parent cultures were used alternately to inoculate the experimental series. The parent cultures were diluted to approximately $50 \%$ after each inoculation to maintain them in exponential phase with a density of approximately $1 \times 10^{5}$ cells ml $^{-1}$ at the time of inoculation. Experimental cultures were initiated at densities of approximately $2 \times 10^{4}$ cells ml $^{-1}$, representing early exponential phase. In total, 2 cultures were started on each of 7 dates between November 27, 2000, and December 18, 2000. These duplicate cultures were the basis for replication in the Coxliella sp. growth experiment. The growth experiment was initiated $1 \mathrm{~d}$ after the last inoculation. First, a FlowCAM (Fluid Imaging Technologies) was used to determine cell density in each $H$. akashiwo culture (range: $2.99 \times 10^{4}$ to $2.61 \times$ $10^{5}$ cells $\mathrm{ml}^{-1}$ ). Second, 2 experimental bottles containing Coxliella sp. were established for each of the $14 \mathrm{H}$. akashiwo cultures in the age series, as well as 2 control bottles that would not have $H$. akashiwo added, for a total of 30 bottles. Half of these bottles also contained 1 $\times 10^{4}$ cells ml ${ }^{-1}$ Rhodomonas sp. $H$. akashiwo cells were added to the experimental bottles at a density of $2 \times$ $10^{3}$ cells $\mathrm{ml}^{-1}$ (Table 2). Incubation volume was $75 \mathrm{ml}$.

Effect of Heterosigma akashiwo on ingestion of Rhodomonas sp. Experiments were conducted with Metacylis sp. and Amphidinium longum to determine whether the presence of Heterosigma akashiwo altered their ingestion of Rhodomonas sp. Metacylis sp. and $A$. longum were chosen as experimental subjects because they differed in their growth response to $H$. akashiwo and because they have different prey ingestion strategies (phagocytosis vs. myzocytosis, respectively). For each experiment, triplicate bottles were set up containing the treatments: (1) Rhodomonas sp.; (2) H. akashiwo CCMP452; and (3) Rhodomonas sp.+ H. akashiwo (Table 2). Initial Rhodomonas sp. and $H$. akashiwo concentrations were $1 \times 10^{4}$ and $2 \times 10^{3}$ cells $\mathrm{ml}^{-1}$, respectively, and incubation volume was $60 \mathrm{ml}$. Because our previous observations indicated that $A$. longum does not ingest $H$. akashiwo, the $H$. akashiwo-only treatment was omitted for that experiment. For Metacylis sp., $10 \mathrm{ml}$ samples were taken at the start of the experiment and 1.5 and $4.5 \mathrm{~h}$ after the grazers were added. The $A$. longum experiment was sampled 0, 10, 20, and $30 \mathrm{~min}$ after grazer addition. Grazers were fixed in glutaraldehyde and examined using epifluorescent microscopy. For Metacylis sp., the number of ingested Rhodomonas sp. and/or $H$. akashiwo cells were counted for approximately 100 ciliates on each slide. For A. longum, ingestion of individual prey cells could not be quantified. Instead, approximately 200 dinoflagellates per slide were scored as to whether or not they contained any ingested Rhodomonas sp. 
For both experiments, the percentage of grazers with ingested food was calculated for each bottle and time point. For the Metacylis sp. experiment, numbers of ingested prey were converted to pg C using measured C content values of $27.7 \mathrm{pg} \mathrm{cell}^{-1}$ for Rhodomonas sp. and $218.3 \mathrm{pg}$ cell $^{-1}$ for Heterosigma akashiwo CCMP452 (M. J. Zirbel \& S. Strom unpubl. data).

Statistical analyses. Effect of Heterosigma akashiwo on protist growth rate: Grazer abundance data were analyzed using ANOVAR $(\alpha=0.05)$ (SPSS 10.0). Where the assumption of sphericity was violated, the HuynhFeldt epsilon was used to adjust the degrees of freedom. A sequential Bonferroni correction (Peres-Nato 1999) was applied to the table of ANOVAR p-values, with the resulting corrected alpha $=0.05$. When significant differences between treatments were indicated, a priori contrasts were used to make specific comparisons. The contrasts were: (1) starved control vs. Heterosigma akashiwo treatments; (2) Rhodomonas sp. vs. Rhodomonas sp. + H. akashiwo treatments; (3) $H$. akashiwo CCMP452 vs. H. akashiwo CCMP1914; (4) Rhodomonas sp. + H. akashiwo CCMP452 vs. Rhodomonas sp. + H. akashiwo CCMP1914; and (5) $H$. akashiwo treatments vs. Rhodomonas sp. + H. akashiwo treatments.

Heterosigma akashiwo concentration gradient effect on tintinnid abundance: Abundance data were analyzed as described above, except that significant ANOVAR results were followed by Helmert contrasts to compare each concentration of $H$. akashiwo to the higher concentrations.

Effect of Heterosigma akashiwo filtrate on Metacylis sp. abundance: Abundance data for Rhodomonas sp.-fed and unfed treatments were grouped and analyzed separately using ANOVAR $(\alpha=0.05)$.

'Age of culture' effect on Coxliella growth rate: Growth rate data were examined using ANOVAR.

Effect of Heterosigma akashiwo on ingestion of Rhodomonas sp.: The percentage of grazers containing ingested food was calculated for each day, and the results were compared using ANOVAR $(\alpha=0.05)$. For the experiment with Metacylis sp., Scheffé's post-hoc test was used to determine homogeneous subsets. Also for the Metacylis sp. experiment, pg of ingested Rhodomonas sp. carbon for each treatment were compared at the 1.5 and $4.5 \mathrm{~h}$ time points using ANOVA $(\alpha=0.05)$.

\section{RESULTS}

\section{Effect of Heterosigma akashiwo on protist growth rate}

All protist grazers except the heterotrophic dinoflagellate Amphidinium longum ingested Heterosigma akashiwo. However, the 7 grazer species exhibited a range of growth responses to the raphidophyte, which proved toxic to some, nutritionally insufficient to others, and able to support survival or growth in 2 species. $H$. akashiwo was toxic to the 3 largest ciliates: Coxliella sp., Metacylis sp., and the chloroplast-retaining Strombidium sp. SPMC68. Ciliate growth rates were lower on both strains of $H$. akashiwo than when starved (Fig. 1, Table 3). This toxic effect was not ameliorated by the addition of Rhodomonas sp. (Fig. 1,

Table 3. Protist grazer growth rates (doublings $\mathrm{d}^{-1} \pm 1 \mathrm{SD}$ ) in experiments testing the effect of Heterosigma akashiwo alone and in mixtures with Rhodomonas sp. (see Fig. 1). Rates were calculated based on initial and final abundances, except where otherwise noted

\begin{tabular}{|c|c|c|c|c|c|c|}
\hline Grazer & Starved & Rhodomonas sp. & $\begin{array}{l}\text { H. akashiwo } \\
\text { CCMP452 }\end{array}$ & $\begin{array}{l}\text { H. akashiwo } \\
\text { CCMP1914 }\end{array}$ & $\begin{array}{c}\text { Rhodomonas sp. + } \\
\text { H. akashiwo } \\
\text { CCMP452 }\end{array}$ & $\begin{array}{c}\text { Rhodomonas sp. + } \\
\text { H. akashiwo } \\
\text { CCMP1914 }\end{array}$ \\
\hline Coxliella sp. & $-1.88 \pm 0.24^{\mathrm{a}}$ & $-0.62 \pm 0.11$ & $-2.95 \pm 0.32^{\mathrm{a}}$ & $-4.04 \pm 0.34^{\mathrm{a}}$ & $-2.33 \pm 0.35$ & $-2.52 \pm 0.17$ \\
\hline Metacylis sp. & $-0.78 \pm 0.09$ & $-0.47 \pm 0.06$ & $-1.77 \pm 0.05$ & $-1.76 \pm 0.16$ & $-2.18 \pm 0.15$ & $-1.77 \pm 0.10$ \\
\hline $\begin{array}{r}\text { Strombidium } \\
\text { sp. SPMC68 }\end{array}$ & $-0.94 \pm 0.23^{a}$ & $-0.41 \pm 0.30^{a}$ & $-2.79 \pm 0.70^{a}$ & $-4.99 \pm 1.49^{a}$ & $-2.84 \pm 1.27^{a}$ & $-4.13 \pm 0.80^{a}$ \\
\hline Eutintinnus sp. & $-0.18 \pm 0.05$ & $0.19 \pm 0.03$ & $-0.12 \pm 0.07$ & $0.03 \pm 0.03$ & $-0.01 \pm 0.06$ & $0.16 \pm 0.05$ \\
\hline $\begin{array}{r}\text { Strombidium } \\
\text { sp. SPMC92 }\end{array}$ & $0.09 \pm 0.18$ & $0.62 \pm 0.09$ & $0.26 \pm 0.08$ & $0.44 \pm 0.14$ & $0.65 \pm 0.13$ & $0.65 \pm 0.07$ \\
\hline $\begin{array}{l}\text { Amphidinium } \\
\text { longum }\end{array}$ & $-0.18 \pm 0.01$ & $0.16 \pm 0.01$ & $-0.18 \pm 0.04$ & $-0.17 \pm 0.01$ & $0.25 \pm 0.05$ & $0.24 \pm 0.12$ \\
\hline $\begin{array}{l}\text { Noctiluca } \\
\text { scintillans }\end{array}$ & $-0.22 \pm 0.03$ & $0.03 \pm 0.01$ & $-0.01 \pm 0.02$ & $-0.02 \pm 0.02$ & $0.01 \pm 0.01$ & $0.03 \pm 0.02$ \\
\hline
\end{tabular}



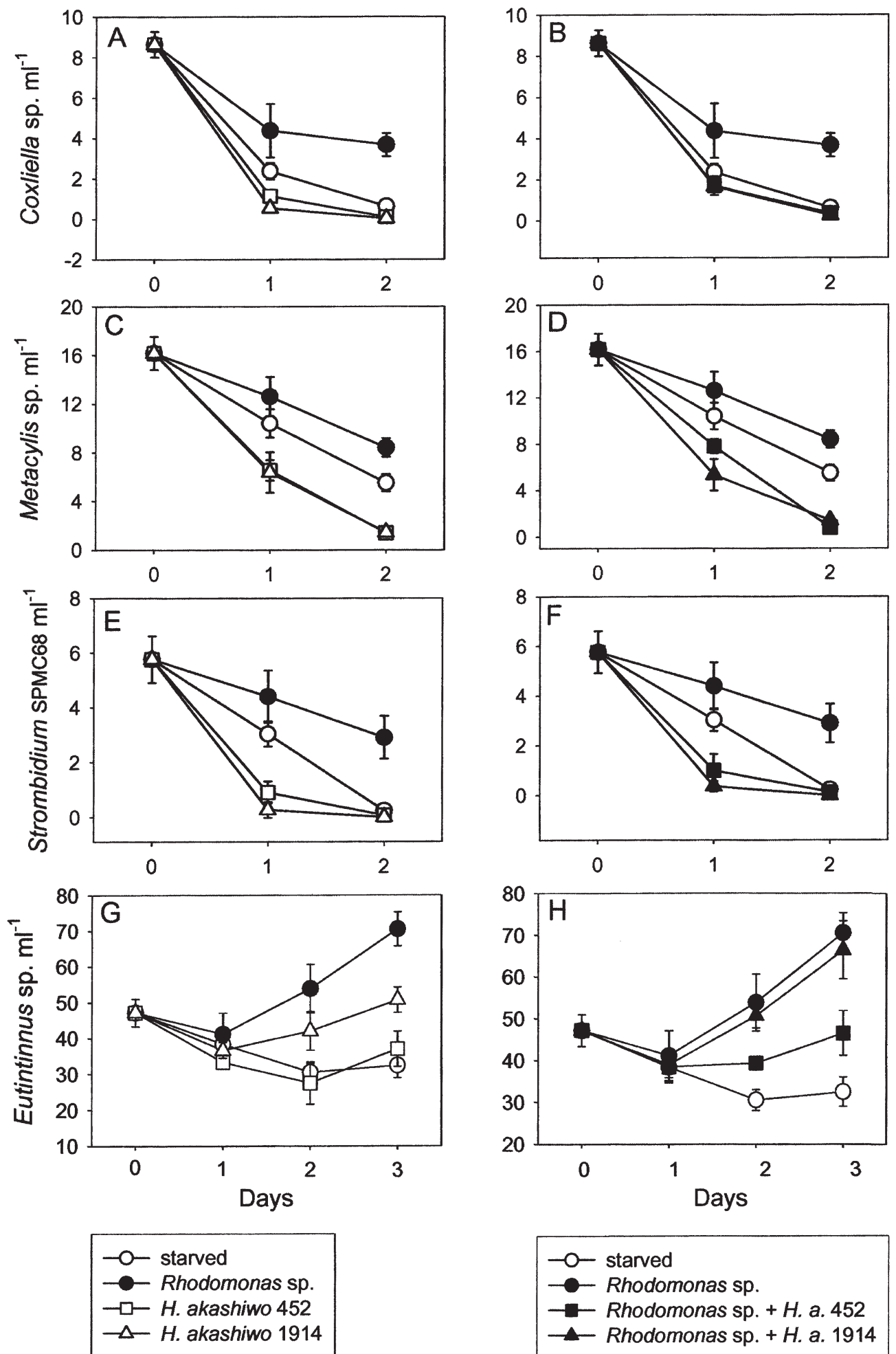

Fig. 1. (Above and following page.) Results of protist growth rate experiments, showing effect of 2 Heterosigma akashiwo (H. a.) strains (CCMP452, CCMP1914) on the abundance of (A,B) Coxliella sp., (C,D) Metacylis sp., (E,F) Strombidium sp. SPMC68, $(\mathrm{G}, \mathrm{H})$ Eutintinnus sp., (I,J) Amphidinium longum, $(\mathrm{K}, \mathrm{L})$ Strombidium sp. SPMC92, and $(\mathrm{M}, \mathrm{N})$ Noctiluca scintillans. Results of each growth experiment have been separated into 2 graphs for clarity: left-hand panels for each grazer species include data for $H$. akashiwo treatments, while right-hand panels include data for mixed-diet treatments. Both panels include data from starved and Rhodomonas sp.-fed controls. See Table 2 for experiment conditions. Error bars: \pm 1 SD $(n=3)$ 

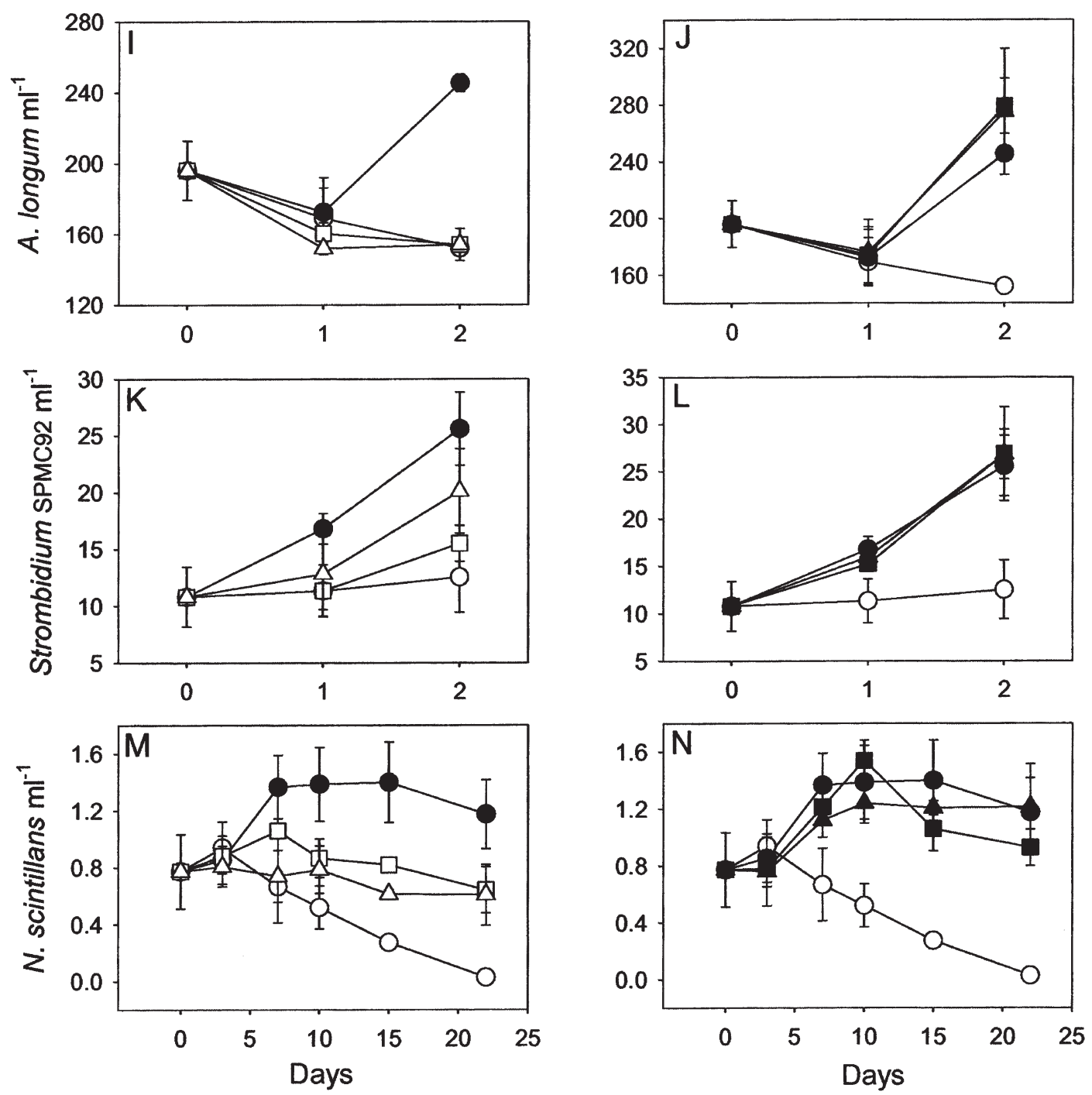

Fig. 1 (continued)

Table 3); we observed no difference between the growth rates on $H$. akashiwo alone and those on $H$. akashiwo combined with Rhodomonas sp. (statistical results for all growth rate experiments [Fig. 1] are reported in Table 4).

Eutintinnus sp. was the only grazer that grew at different rates on the 2 strains of Heterosigma akashiwo (Fig. 1, Table 3). Strain CCMP1914 supported higher growth rates than strain CCMP452. The former supported some tintinnid growth between Days 1 and 3, though less than the high-quality Rhodomonas sp. diet. Growth on the latter strain was indistinguishable from growth in the starved control, indicating complete nutritional insufficiency but not toxicity. This interpretation is supported by the mixed diet results. Addition of CCMP452 to Rhodomonas sp. reduced growth rates relative to a diet of Rhodomonas sp. alone, whereas addition of CCMP1914 did not (Fig. 1).

Amphidinium longum and Strombidium sp. SPMC92 were unaffected by either strain of Heterosigma akashiwo, whether in single prey or mixed-diet treatments. Noctiluca scintillans, on the other hand, clearly received some modest nutritional benefit from $H$. akashiwo, which supported survival of the dinoflagellate over the $22 \mathrm{~d}$ course of the growth experiment (Fig. 1). This level of growth was better than that in the starved controls, in which $N$. scintillans abundance slowly declined, but worse than that in the Rhodomonas sp. treatment. Growth in the $H$. akashiwo + Rhodomonas sp. mixtures was indistinguishable from growth on Rhodomonas alone (Fig. 1, Table 3). 
Table 4. Results of statistical analyses (p-values) for experiments testing the effect of Heterosigma akashiwo on protist growth. All experiments showed significant effects of treatment (ANOVAR, $\alpha=0.05$ ). The 5 a priori contrasts specifically compared: (1) Starved vs. H. akashiwo treatments; (2) Rhodomonas sp. vs. H. akashiwo + Rhodomonas sp. treatments; (3) $H$. akashiwo CCMP452 vs. H. akashiwo CCMP1914; (4) $H$. akashiwo CCMP452 + Rhodomonas sp. vs. H. akashiwo CCMP1914 + Rhodomonas sp.; (5) H. akashiwo vs. H. akashiwo + Rhodomonas sp. treatments. ${ }^{*}$ Significant p-values $(\alpha=0.05)$

\begin{tabular}{|c|c|c|c|c|c|}
\hline \multirow[t]{2}{*}{ Grazer } & \multicolumn{5}{|c|}{ Contrasts } \\
\hline & 1 & 2 & 3 & 4 & 5 \\
\hline Coxliella sp. & $0.012^{*}$ & $<0.001^{*}$ & 0.429 & 0.873 & 0.080 \\
\hline Metacylis sp. & $<0.001^{*}$ & $<0.001^{*}$ & 0.927 & 0.216 & 0.847 \\
\hline $\begin{array}{l}\text { Strombi- } \\
\text { dium sp. } \\
\text { SPMC68 }\end{array}$ & $0.022^{*}$ & $<0.001^{*}$ & 0.559 & 0.523 & 0.874 \\
\hline $\begin{array}{l}\text { Eutintinnus } \\
\text { sp. }\end{array}$ & 0.090 & $0.003^{*}$ & $0.002^{*}$ & $0.001^{*}$ & $<0.001^{*}$ \\
\hline $\begin{array}{r}\text { Strombidium } \\
\text { sp. SPMC92 }\end{array}$ & 0.250 & 0.992 & 0.309 & 0.905 & $0.009^{*}$ \\
\hline $\begin{array}{l}\text { Amphidinium } \\
\text { longum }\end{array}$ & 0.698 & 0.232 & 0.796 & 0.950 & $<0.001^{*}$ \\
\hline $\begin{array}{l}\text { Noctiluca } \\
\text { scintillans }\end{array}$ & $0.025^{*}$ & 0.283 & 0.306 & 0.977 & $0.005^{*}$ \\
\hline
\end{tabular}

\section{Heterosigma akashiwo concentration gradient effect on tintinnid abundance}

Ciliate abundance decreased with increasing Heterosigma akashiwo concentration for both Coxliella sp. and Metacylis sp. (Fig. 2). In the Coxliella sp. experiment, all treatments containing $H$. akashiwoyielded significantly lower ciliate abundance than the Rhodomonas sp. only control, and ciliate abundance decreased with increasing $H$. akashiwo concentration (ANOVAR, $\alpha=0.05, \mathrm{p}<0.001$; all contrasts, $\mathrm{p}<$ 0.006). We observed the same effects when Metacylis sp. was the grazer species (ANOVAR, $\alpha=0.05, \mathrm{p}<$ 0.001; all contrasts, $\mathrm{p}<0.001)$. On Day 2 of both experiments, ciliate abundances at the lowest $H$. akashiwo concentration were higher than abundances in the starved controls (compare open and filled squares in Fig. 2).

\section{Effect of Heterosigma akashiwo filtrate on Metacylis sp. abundance}

Neither the Rhodomonas sp. filtrate nor the Heterosigma akashiwo filtrate had any effect on the abundance of Metacylis sp. (Fig. 3), either in unfed (ANOVAR, $\mathrm{p}=0.143$ ) or fed (ANOVAR, $\mathrm{p}=0.071$ ) treatments.
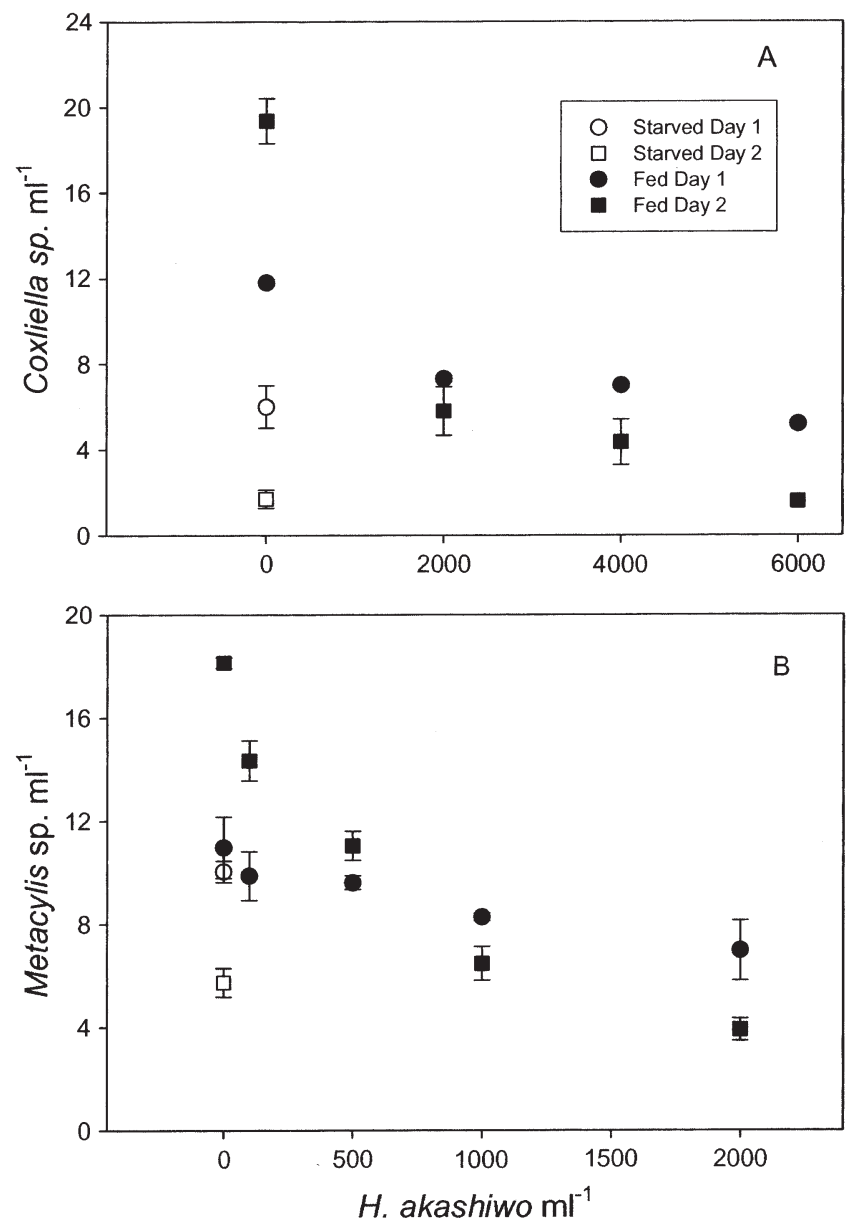

Fig. 2. Effect of varying concentrations of Heterosigma akashiwo CCMP452 on the abundance of (A) Coxliella sp. and (B) Metacylis sp. in a mixed-algal diet. See Table 2 for experiment conditions. Error bars: $\pm 1 \mathrm{SD}(\mathrm{n}=2)$

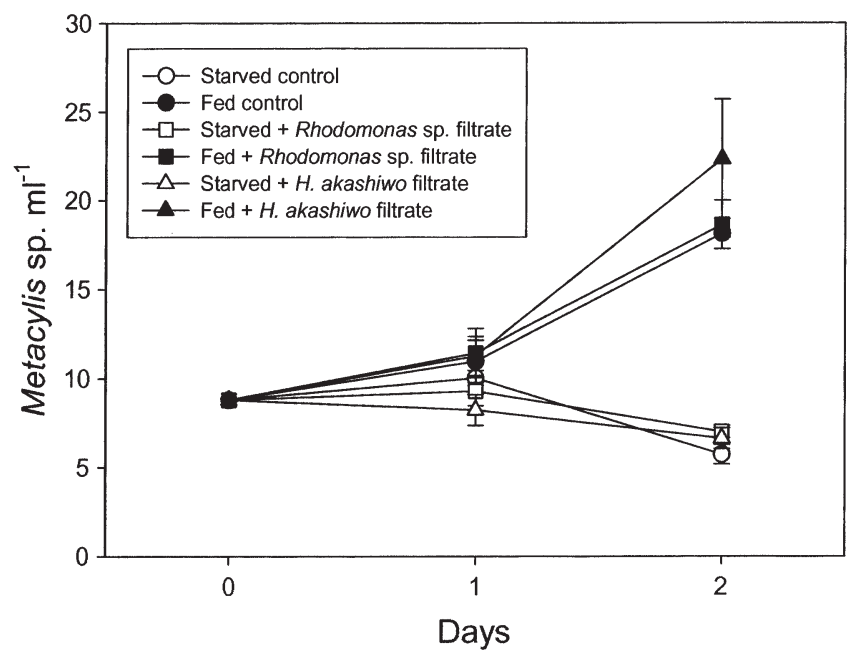

Fig. 3. Effect of Rhodomonas sp. and Heterosigma akashiwo culture filtrates on the abundance of Metacylis sp. Filtrates comprised $10 \%$ of total experiment volume. See Table 2 for experiment conditions. Error bars: $\pm 1 \mathrm{SD}(\mathrm{n}=3)$ 


\section{'Age of culture' effect on Coxliella sp. growth rate}

The age of the Heterosigma akashiwo culture clearly influenced the growth rate of Coxliella sp. (ANOVAR, $p=0.015$ ), with prey from younger cultures leading to a higher ciliate growth rate (lower mortality rate) than prey from the oldest cultures (Fig. 4). We observed a non-linear response of mortality to culture age, with cultures from 1 to $12 \mathrm{~d}$ old becoming increasingly toxic with age, and cultures older than $12 \mathrm{~d}$ all approximately equivalent in toxicity. All treatments with $H$. akashiwo alone led to greater ciliate mortality than the starved controls (open vs. filled circles in Fig. 4), confirming the toxicity seen during the Coxliella sp. growth experiment (Fig. 1). In contrast to the Coxliella sp. growth experiment (Fig. 1, Table 3), addition of Rhodomonas sp. to the $H$. akashiwo diet did reduce mortality (increase growth) in the 'age of culture' experiment. We saw this increase regardless of $H$. akashiwo culture age (ANOVAR, $\mathrm{p}<0.001$ ), but mixed diets overall supported substantially lower growth than the Rhodomonas sp.-only controls. There was no interaction between diet (H. akashiwo alone vs. mixed) and culture age effects on growth (ANOVAR, p = $0.762)$

\section{Effect of Heterosigma akashiwo on ingestion of Rhodomonas sp.}

The presence of Heterosigma akashiwo had no effect on Amphidinium longum's feeding on Rhodomonas sp. (ANOVAR, $\mathrm{p}=0.158$ ). Approximately $25 \%$ of the dinoflagellates had fed on Rhodomonas sp. after 30 min in treatments with and without $H$. akashiwo. As in the growth experiment, $A$. longum did not eat H. akashiwo at all. Similarly, the percentage of Metacylis sp. with ingested food was the same for the Rhodomonas sp.-only and Rhodomonas sp. $+H$. akashiwo treatments, with a lower percentage eating

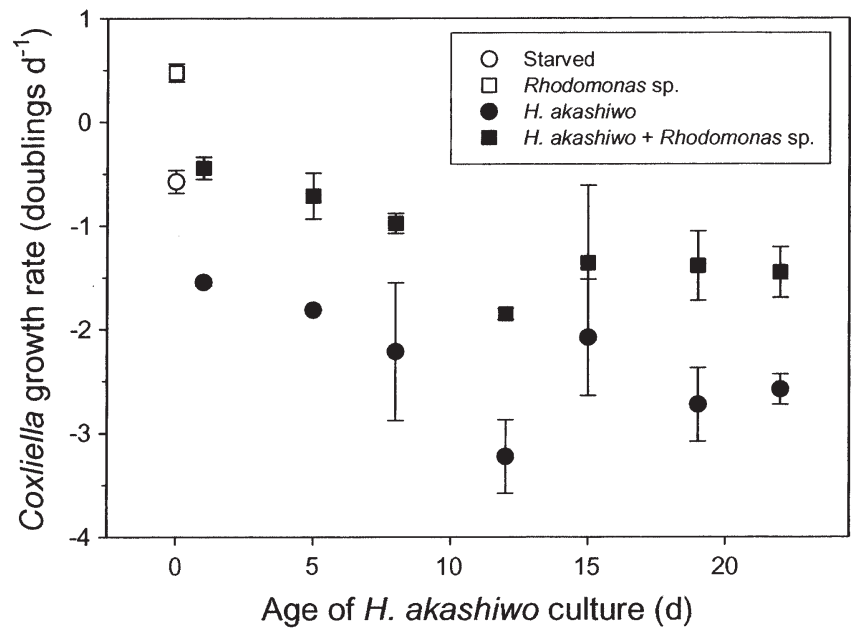

Fig. 4. Average growth rates of Coxliella sp. when fed Heterosigma akashiwo CCMP452 from cultures of varying ages, with or without added Rhodomonas sp. See Table 2 for experiment conditions. Error bars: $\pm 1 \mathrm{SD}(\mathrm{n}=2)$

H. akashiwo alone (ANOVAR, $\mathrm{p}<0.001)$ (Table 5). The amount of algal $\mathrm{C}$ ingested per ciliate was, however, higher on the $H$. akashiwo than on the Rhodomonas sp. diet, perhaps due to the greater prey availability in the $H$. akashiwo treatment or to the lower $\mathrm{C}$ density of the

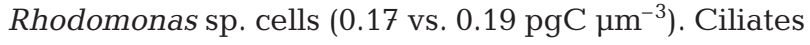
contained approximately the same total amount of ingested $\mathrm{C}$ when fed the mixed diet as when fed $H$. akashiwo alone (1.5 h: 32.4 vs. $34.4 \mathrm{pgC}$ ciliate $^{-1} ; 4.5 \mathrm{~h}$ : 46.1 vs. $43.0 \mathrm{pgC}$ ciliate $^{-1}$ ). In addition, the ratio of $H$. akashiwo $\mathrm{C}$ to Rhodomonas sp. C in the food vacuoles was similar at the 2 time points (ca. 2:1). Assuming that both $H$. akashiwo and mixed-diet prey levels were above levels at which Metacylis sp. feeding rates saturate, the addition of $H$. akashiwo to the Rhodomonas sp. diet had no effect on either the percentage of ciliates in the population that were feeding, or on the overall amount of prey $\mathrm{C}$ ingested.

Table 5. Ingestion of Rhodomonas sp. and Heterosigma akashiwo by Metacylis sp. after 1.5 and $4.5 \mathrm{~h}$ of feeding $( \pm 1 \mathrm{SD}, \mathrm{n}=3)$. $\%$ feeding: percentage of ciliates with ingested prey. Available prey: $\mu \mathrm{gC} \mathrm{l}^{-1}$. Ingested Rhodomonas sp. or H. akashiwo: pgC ciliate $^{-1}$. na: prey species not available in the treatment listed

\begin{tabular}{|c|c|c|c|c|c|c|c|}
\hline \multirow{2}{*}{ Diet } & \multirow{2}{*}{$\begin{array}{c}\text { Available } \\
\text { prey }\end{array}$} & \multirow{2}{*}{$\%$ feeding } & \multirow{2}{*}{$\begin{array}{c}\text { Ingested } \\
\text { Rhodomonas }\end{array}$} & \multirow[b]{2}{*}{$\begin{array}{l}\text { Ingested } \\
\text { H. akashiwo }\end{array}$} & \multirow[b]{2}{*}{$\%$ Feeding } & \multirow{2}{*}{$\begin{array}{c}4.5 \mathrm{~h} \\
\text { Ingested } \\
\text { Rhodomonas }\end{array}$} & \multirow[b]{2}{*}{$\begin{array}{c}\text { Ingested } \\
\text { H. akashiwo }\end{array}$} \\
\hline & & & & & & & \\
\hline Rhodomonas sp. & 277 & $29.8 \pm 2.5$ & $10.4 \pm 0.5$ & na & $46.2 \pm 3.3$ & $19.5 \pm 0.9$ & na \\
\hline H. akashiwo & 437 & $14.1 \pm 3.3$ & na & $34.4 \pm 3.2$ & $17.8 \pm 0.1$ & na & $43.0 \pm 1.5$ \\
\hline $\begin{array}{l}\text { Rhodomonas sp. } \\
+ \text { H. akashiwo }\end{array}$ & 714 & $35.5 \pm 1.6$ & $10.5 \pm 0.2$ & $21.9 \pm 5.7$ & $43.9 \pm 0.8$ & $13.7 \pm 1.0$ & $32.4 \pm 3.2$ \\
\hline
\end{tabular}




\section{DISCUSSION}

Both tested strains of Heterosigma akashiwo were toxic to 3 species of choreotrich ciliates; Coxliella sp., Metacylis sp. and the larger Strombidium sp. all experienced higher mortality when fed the raphidophyte than when starved. Although another large tintinnid, Favella taraikaensis, was seen to reject $H$. akashiwo cells in high-speed video work (Taniguchi \& Takeda 1988), these 3 ciliate species were not capable of avoiding the toxic cells. We observed ingestion by all 3 species during the growth experiments, and substantial feeding by Metacylis in the ingestion experiment (Table 5). Toxicity of $H$. akashiwo (then considered Olisthodiscus luteus) to 2 tintinnid species was also reported by Verity \& Stoecker (1982). They observed mortality greater than that in starved controls for Tintinnopsis tubulosoides fed strain OL-1, and for Favella sp. fed strain Olisth (the same as CCMP452, one of the 2 strains used in our study).

Conditions during our experiments were consistent with those eliciting greatest ichthyotoxicity in 2 Japanese Heterosigma akashiwo strains (Ono et al. 2000, Haque \& Onoue 2002). These include: very low light levels, 30 psu salinity, an $H$. akashiwo growth temperature of $15^{\circ} \mathrm{C}$, and an experiment temperature of $12^{\circ} \mathrm{C}$. Further support for the existence of toxicity in our strains comes from a recent study of $H$. akashiwoproduced extracellular organics. Twiner et al. (2004) found that organics from strain NEPCC560R (the same as CCMP452, used in the present study) reduced respiratory activity of mammalian cells to less than half of control rates.

While Heterosigma akashiwo was toxic to 3 ciliate species in our experiments, other protist grazers experienced no toxicity. At least one of these grazers (the dinoflagellate Amphidinium longum) did not ingest $H$. akashiwo cells, and the presence of $H$. akashiwo had no effect on growth relative to starved or Rhodomonas sp. control treatments. The same result was observed for the smaller Strombidium sp. While this ciliate did ingest the raphidophyte, we have no information on the quantity of cells eaten or the duration of feeding; a low feeding rate or short feeding duration could have alleviated any toxic effects. Eutintinnus sp. and Noctiluca scintillans clearly derived nutritional benefit from H. akashiwo. When fed the raphidophyte alone they fared better than in starved controls, and their growth on Rhodomonas sp. was not reduced by the addition of $H$. akashiwo to their diet. The higher growth rate of Eutintinnus sp. on H. akashiwo CCMP1914 than on strain CCMP452 demonstrates a nutritional difference between the strains; whether this was due to greater ingestion of CCMP1914 or to inter-strain differences in biochemical composition is not known. Differences between strains were sufficiently subtle that they had no effect on the other 6 protist grazers.

The range of growth responses seen in the 7 grazer species we studied is consistent with literature reports for other protists. Some species ingested and grew on monospecific diets of Heterosigma akashiwo, including the prostomatid ciliate Tiarina fusus (Jeong et al. 2002) and the heterotrophic dinoflagellates Oxyrrhis marina and Noctiluca scintillans (Nakamura 1998, Jeong et al. 2003). Other species did not ingest $H$. akashiwo, including Favella taraikaensis (Taniguchi \& Takeda 1988) and F. ehrenbergii (Kamiyama \& Arima 2001). In contrast, the Favella sp. studied by Verity \& Stoecker (1982) did ingest $H$. akashiwo and was killed by it. These differences among Favella studies could be due to the various Favella species used, or to differences among $H$. akashiwo strains and growth conditions. Indeed, strain differences could explain even the varying responses of different grazer species, as summarized above. Unfortunately, $H$. akashiwo strain identities were not reported for several of these studies. Other harmful algal species show marked inter-strain variability in nutritional value and toxicity to protists, including Alexandrium tamarense (Hansen 1989, Tillmann \& John 2002), Pfiesteria piscicida (Stoecker et al. 2000), Chrysochromulina polylepis (John et al. 2002), Emiliania huxleyi (Strom et al. 2003), and Prorocentrum minimum (Rosetta \& McManus 2003).

Our observations of Heterosigma akashiwo toxicity toward large ciliates is consistent with field observations of microzooplankton community composition during $H$. akashiwo blooms. Tintinnid abundance varied inversely with $H$. akashiwo (then identified as Olisthodiscus luteus) concentration during blooms in Narragansett Bay (Rhode Island, USA) during 1980-1981 (Verity \& Stoecker 1982). Similarly, the abundance and diversity of microzooplankton, especially tintinnid ciliates, decreased markedly during $H$. akashiwo blooms in Hiroshima Bay, Japan (Kamiyama 1995, Kamiyama et al. 2000). A dense H. akashiwo bloom in Burrard Inlet (Strait of Georgia, British Columbia, Canada) resulted in high mortality rates $\left(-1.5\right.$ to $\left.-2.0 \mathrm{~d}^{-1}\right)$ of tintinnids and large $(>60 \mu \mathrm{m})$ aloricate choreotrichs during $24 \mathrm{~h}$ incubation experiments. Other protist grazers in the community, including smaller aloricate choreotrichs and heterotrophic dinoflagellates, had growth rates near zero (Erenstone 2003). Large choreotrich ciliates often exert substantial grazing pressure on coastal phytoplankton (e.g. Capriulo \& Carpenter 1983, Levinsen \& Nielsen 2002, Johansson et al. 2004). Toxicity of $H$. akashiwo to this component of the microzooplankton community could promote formation of $H$. akashiwo blooms.

Two specific aspects of the Heterosigma akashiwociliate interaction could further influence bloom forma- 
tion and persistence. First is the response to $H$. akashiwo cell concentration. Our results show that sufficiently low concentrations of $H$. akashiwo, in combination with nutritious prey, can be tolerated by ciliates that are otherwise susceptible to the raphidophyte's toxicity. At the lowest concentrations tested, $H$. akashiwo combined with $1 \times 10^{4}$ cells $\mathrm{ml}^{-1}$ Rhodomonas sp. supported higher abundances of Coxliella sp. and Metacylis sp. than did starved controls (2 d time points, Fig. 2). Increasing amounts of $H$. akashiwo, however, led to progressive decreases in ciliates $\mathrm{ml}^{-1}$. Survival of protist grazers at low concentrations of otherwise toxic algae was seen in one other study of $H$. akashiwo (Verity \& Stoecker 1982), as well as in studies of Prymnesium parvum (Rosetta \& McManus 2003) and various dinoflagellates (Hansen 1989, Jeong \& Latz 1994, Hansen 1995, Kamiyama 1997, Kamiyama \& Arima 1997). Decreasing abundance of potential consumers with increasing algal density constitutes a negative feedback, which would promote further accumulation of harmful algal cells. Such feedbacks would be enhanced by the 'age of culture' effect that we observed. H. akashiwo cells from older cultures were more toxic to Coxliella sp. than cells from younger cultures (Fig. 4). Nutrient limitation can increase toxicity in other algal species: Alexandrium fundyense, A. minutum, Prymnesium patelliferum, and Pseudo-nitzschia seriata are all known to be more toxic in stationary than in exponential growth phase (John \& Flynn 2000, Graneli \& Johannson 2003, Lippemeier et al. 2003, Fehling et al. 2004). To the extent that a developing bloom behaves like a batch culture, the combination of increasing $H$. akashiwo cell density and increased toxicity per cell should progressively reduce ciliate abundance and curtail grazing by this component of the microzooplankton community. Avoidance of $H$. akashiwo cells by other types of protist grazers, as seen in our study for Amphidinium longum, would exacerbate the accumulation of the raphidophyte, perhaps at the expense of other more palatable phytoplankton species.

The mechanism of Heterosigma akashiwo's toxicity to marine organisms remains unclear. The literature offers considerable discussion and debate on the subject (see references in 'Introduction', also Twiner et al. 2001, Cembella 2003). Damage to fish gill tissue by ROS is clearly an element of the ichthyotoxicity caused by this and related raphidophytes (Yang et al. 1995, Kim et al. 1999). However, none of the proposed toxic substances (ROS, brevetoxin-like compounds, extracellular organics) has been directly tested on heterotrophic protists, the consumers with the potential to have the largest impact on $H$. akashiwo in nature. The results of our filtrate experiment show that substances toxic to protists, if dissolved, must be short-lived (i.e. requiring the continued presence of the algal cells for effectiveness). The presence of $H$. akashiwo cells did not, however, decrease feeding on Rhodomonas sp. after $4.5 \mathrm{~h}$ (Table 5), nor did $2 \mathrm{~d}$ of exposure decrease survival of Amphidinium longum (Fig. 1), which did not eat the raphidophyte. These observations also do not support the hypothesis that $H$. akashiwo mucus prevents feeding by entangling cilia, as seen for the rotifer Synchaeta cecilia (Egloff 1986, H. akashiwo then considered Olisthodiscus luteus). Rather, it seems highly probable that ingestion of $H$. akashiwo by protists is required for toxicity. H. akashiwo toxicity to ciliates, as observed by us and by Verity \& Stoecker (1982), may arise from a different mechanism than ichthyotoxicity. Tillmann \& John (2002), for example, found that toxic effects of Alexandrium spp. on the heterotrophic dinoflagellate Oxyrrhis marina bore no relationship to the measured paralytic shellfish poisoning toxin content of different Alexandrium strains and species.

In summary, we found that 2 strains of Heterosigma akashiwo were toxic to several protist grazers. Consistent with research on other toxic marine organisms (McClintock \& Baker 2001), different protist grazers showed a range of responses to $H$. akashiwo, with some able to avoid feeding on the cells and others able to survive and grow on the raphidophyte. The 3 largest ciliate species tested, however, were all killed by $H$. akashiwo. No toxicity was associated with filtrate from $H$. akashiwo culture or from the presence of $H$. akashiwo cells that were not ingested, so the toxic effect of this species to large ciliates seems to depend upon ingestion of the cells. Ciliates of the types we studied can be important consumers of coastal phytoplankton. Thus, the toxic effects of $H$. akashiwo could reduce microzooplankton consumption of this species in nature. Effects such as the increase in ciliate mortality with increasing $H$. akashiwo cell concentration and population age would further promote bloom development and persistence. Toxicity of $H$. akashiwo toward ciliates is likely an important element in the ability of this raphidophyte to form persistent blooms.

Acknowledgements. We thank J. Holmes and K. Bright for their assistance with algal and microzooplankton cultures, and B. Bingham for help with statistical analysis. This research was supported by grants from Huxley College of the Environment, the Dean J. Alan Ross Fund and Sigma Xi to J.C., and by Washington Sea Grant \#R/OT-20 to S.S.

\section{LITERATURE CITED}

Calbet A, Landry MR (2004) Phytoplankton growth, microzooplankton grazing, and carbon cycling in marine systems. Limnol Oceanogr 49:51-57

Capriulo GM, Carpenter EJ (1983) Abundance, species composition and feeding impact of tintinnid micro-zooplank- 
ton in Central Long Island Sound. Mar Ecol Prog Ser 10: $277-288$

Carrasquero-Verde JR (1999) Role of associated bacteria in Heterosigma carterae toxicity to salmonids. Aquat Toxicol 45:19-44

Cembella AD (2003) Chemical ecology of eukaryotic microalgae in marine ecosystems. Phycologia 42:420-447

Colin SP, Dam HG (2002) Testing for toxic effects of prey on zooplankton using sole versus mixed diets. Limnol Oceanogr 47:1430-1437

Egloff DA (1986) Effects of Olisthodiscus luteus on the feeding and reproduction of the marine rotifer Synchaeta cecilia. J Plankton Res 8:263-274

Erenstone D (2003) Effects of Heterosigma akashiwo blooms on microzooplankton growth, grazing and community composition. MS thesis, Western Washington University, Bellingham, WA

Fehling J, Davidson K, Bolch CJ, Bates SS (2004) Growth and domoic acid production by Pseudo-nitzschia seriata (Bacillariophyceae) under phosphate and silicate limitation. J Phycol 40:674-683

Fenchel T (1987) Ecology of protozoa. Science Tech Publishers, Madison, WI

Gifford DJ (1985) Laboratory culture of marine planktonic oligotrichs (Ciliophora, Oligotrichida). Mar Ecol Prog Ser 23:257-267

Graneli E, Johannson N (2003) Effects of the toxic haptophyte Prymnesium parvum on the survival and feeding of a ciliate: the influence of different nutrient conditions. Mar Ecol Prog Ser 254:49-56

Guillard RRL, Ryther JH (1962) Studies of marine planktonic diatoms. I. Cyclotella nana Hustedt and Detonula confervacea (Cleve) Gran. Can J Microbiol 8:229-239

Hansen PJ (1989) The red tide dinoflagellate Alexandrium tamarense: effects on behaviour and growth of a tintinnid ciliate. Mar Ecol Prog Ser 53:105-116

Hansen PJ (1995) Growth and grazing response of a ciliate feeding on the red tide dinoflagellate Gyrodinium aureolum in monoculture and in mixture with a non-toxic alga. Mar Ecol Prog Ser 121:65-72

Haque SM, Onoue Y (2002) Effects of salinity on growth and toxin production of a noxious phytoflagellate, Heterosigma akashiwo (Raphidopyceae). Botanica Marina 45:356-363

Hara Y, Chihara M (1987) Morphology, ultrastructure and taxonomy of the raphidophycean alga Heterosigma akashiwo. Bot Mag Tokyo 100:151-163

Hershberger PK, Rensel JE, Matter AL, Taub FB (1997) Vertical distribution of the chloromonad flagellate Heterosigma carterae in columns: implications for bloom development. Can J Fish Aquat Sci 54:2228-2234

Honjo T (1993) Overview on bloom dynamics and physiological ecology of Heterosigma akashiwo. In: Smayda TJ, Shimizu Y (eds) Toxic phytoplankton blooms in the sea. Elsevier, Amsterdam, p 33-41

Horner RA, Garrison DL, Plumley FG (1997) Harmful algal blooms and red tide problems on the U.S. west coast. Limnol Oceanogr 42:1076-1088

Jeong HJ, Latz MI (1994) Growth and grazing rates of the heterotrophic dinoflagellates Protoperidinium spp. on red tide dinoflagellates. Mar Ecol Prog Ser 106:173-185

Jeong HJ, Yoon JY, Kim JS, Yoo YD, Seong KA (2002) Growth and grazing rates of the prostomatid ciliate Tiarina fusus on red-tide and toxic algae. Aquat Microb Ecol 28: 289-297

Jeong HJ, Kim JS, Yoo YD, Kim ST and 6 others (2003) Feeding by the heterotrophic dinoflagellate Oxyrrhis marina on the red-tide raphidophyte Heterosigma akashiwo: a potential biological method to control red tides using mass-cultured grazers. J Eukaryot Microbiol 50:274-282

Johansson M, Gorokhova E, Larsson U (2004) Annual variability in ciliate community structure, potential prey and predators in the open northern Baltic Sea proper. J Plankton Res 26:67-80

John EH, Flynn KJ (2000) Growth dynamics and toxicity of Alexandrium fundyense (Dinophyceae): the effect of changing N:P supply ratios on internal toxin and nutrient levels. Eur J Phycol 35:11-23

John U, Tillmann U, Medlin LK (2002) A comparative approach to study inhibition of grazing and lipid composition of a toxic and non-toxic clone of Chrysochromulina polylepis (Prymnesiophyceae). Harmful Algae 1:45-57

Jonasdottir SH, Kiørboe T, Tang KW, St. John M, Visser AW, Saiz E, Dam HG (1998) Role of diatoms in copepod egg production: good, harmless or toxic? Mar Ecol Prog Ser 172:305-308

Kamiyama T (1995) Change in the microzooplankton community during decay of a Heterosigma akashiwo bloom. J Oceanogr 51:279-287

Kamiyama T (1997) Growth and grazing responses of tintinnid ciliates feeding on the toxic dinoflagellate Heterocapsa circularisquama. Mar Biol 128:509-515

Kamiyama T, Arima S (1997) Lethal effect of the dinoflagellate Heterocapsa circularisquama upon the tintinnid ciliate Favella taraikaensis. Mar Ecol Prog Ser 160:27-33

Kamiyama T, Arima S (2001) Feeding characteristics of two tintinnid ciliate species on phytoplankton including harmful species: effects of prey size on ingestion rates and selectivity. J Exp Mar Biol Ecol 257:281-296

Kamiyama T, Itakura S, Nagasaki K (2000) Changes in microbial loop components: effects of a harmful algal bloom formation and its decay. Aquat Microb Ecol 21:21-30

Khan S, Arakawa O, Onoue Y (1997) Neurotoxins in a toxic red tide of Heterosigma akashiwo (Raphidophyceae) in Kagoshima Bay, Japan. Aquac Res 28:9-14

Kim CS, Lee GL, Lee CK, Kim HG, Jung J (1999) Reactive oxygen species as causative agents in the ichtyotoxicity of the red tide dinoflagellate Cochlodinium polykrikoides. J Plankton Res 21:2105-2115

Levinsen H, Nielsen TG (2002) The trophic role of marine pelagic ciliates and heterotrophic dinoflagellates in Arctic and temperate coastal ecosystems: a cross-latitude comparison. Limnol Oceanogr 47:427-439

Lippemeier S, Frampton DM, Blackburn SI, Geier SC, Negri AP (2003) Influence of phosphorus limitation on toxicity and phtosynthesis of Alexandrium minutum (Dinophyceae) monitored by in-line detection of variable chlorophyll fluorescence. J Phycol 39:320-331

Marshall J, Nichols PD, Hamilton B, Lewis RJ, Hallegraeff GM (2003) Ichthyotoxicity of Chatonella marina (Raphidophyceae) to damselfish (Acanthochromis polycanthus): the synergistic fole of reactive oxygen species and free fatty acids. Harmful Algae 2:273-281

McClintock JB, Baker BJ (eds) (2001) Marine chemical ecology. CRC Marine Science Series, CRC Press, Boca Raton, FL

Nakamura A, Okamoto T, Komatsu N, Ooka S, Oka T, Ishimatsu A, Muramatsu T (1998) Fish mucus stimulates the generation of superoxide anion by Chatonella marina and Heterosigma akashiwo. Fish Sci 64:866-869

Nakamura Y (1998) Growth and grazing of a large heterotrophic dinoflagellate, Noctiluca scintillans, in laboratory cultures. J Plankton Res 20:1711-1720

Oda T, Nakamura A, Shikayama M, Kawano I, Ishimatsu A, Muramatsu T (1997) Generation of reactive oxygen spe- 
cies by raphidophycean phytoplankton. Biosci Biotechnol Biochem 61:1658-1662

Oda T, Nakamura A, Okamoto T, Ishimatsu A, Muramatsu T (1998) Lectin-induced enhancement of superoxide anion production by red tide phytoplankton. Mar Biol 131: 383-390

Ono K, Khan S, Onoue Y (2000) Effects of temperature and light intensity on the growth and toxicity of Heterosigma akashiwo (Raphidophyceae). Aquac Res 31:427-433

Peres-Nato PR (1999) How many statistical tests are too many? The problem of conducting multiple ecological inferences revisited. Mar Ecol Prog Ser 176:303-306

Pratt DM (1966) Competition between Skeletonema costatum and Olisthodiscus luteus in Narragansett Bay and in culture. Limnol Oceanogr 11:447-455

Rosetta CH, McManus GB (2003) Feeding by ciliates on two harmful algal bloom species, Prymnesium parvum and Prorocentrum minimum. Harmful Algae 2:109-126

Stoecker DK, Stevens K, Gustafson DE (2000) Grazing on Pfiesteria piscicida by microzooplankton. Aquat Microb Ecol 22:261-270

Strom SL (2002) Novel interactions between phytoplankton and microzooplankton: their influence on the coupling between growth and grazing rates in the sea. Hydrobiologia 480:41-54

Strom SL, Morello TA (1998) Comparative growth rates and yields of ciliates and heterotrophic dinoflagellates. J Plankton Res 20:571-584

Strom SL, Wolfe GV, Holmes J, Stecher HA, Shimeneck C, Lambert S, Moreno E (2003) Chemical defense in the microplankton. I: Feeding and growth rates of heterotrophic protists on the DMS-producing phytoplankter Emiliania huxleyi. Limnol Oceanogr 48:217-229

Taniguchi A, Takeda Y (1988) Feeding rate and behavior of

Editorial responsibility: David A. Caron,

Los Angeles, California, USA the tintinnid ciliate Favella taraikaensis, observed with a high speed VTR system. Mar Microb Food Webs 3:21-34

Taylor FJR, Haigh R (1993) The ecology of fish-killing blooms of the chloromonad flagellate Heterosigma in the Strait of Georgia and adjacent waters. In: Smayda TJ, Shimizu Y (eds) Toxic phytoplankton blooms in the sea. Elsevier, Amsterdam, p 705-710

Throndsen J (1996) Note on the taxonomy of Heterosigma akashiwo (Raphidophyceae). Phycologia 35:367

Tillmann U, John U (2002) Toxic effects of Alexandrium spp. on heterotrophic dinoflagellates: an allelochemical defence mechanism independent of PSP-toxin content. Mar Ecol Prog Ser 230:47-58

Twiner MJ, Trick CG (2000) Possible physiological mechanisms for production of hydrogen peroxide by the ichthyotoxic flagellate Heterosigma akashiwo. J Plankton Res 22:1961-1975

Twiner MJ, Dixon J, Trick CG (2001) Toxic effects of Heterosigma akashiwo do not appear to be mediated by hydrogen peroxide. Limnol Oceanogr 46:1400-1405

Twiner MJ, Dixon SJ, Trick CG (2004) Extracellular organics from specific cultures of Heterosigma akashiwo (Raphidophyceae) irreversibly alter respiratory activity in mammalian cells. Harmful Algae 3:173-182

Verity PG, Stoecker D (1982) Effects of Olisthodiscus luteus on the growth and abundance of tintinnids. Mar Biol 72: 79-87

Yang CZ, Albright LJ, Yousif AN (1995) Oxygen-radicalmediated effects of the toxic phytoplankter Heterosigma carterae on juvenile rainbow trout Oncorhynchus mykiss. Dis Aquat Org 23:101-108

Zirbel MJ (2001) Evidence for light-enhanced grazing and growth in two species of marine microzooplankton. MS thesis, Western Washington University, Bellingham, WA

Submitted: April 12, 2004; Accepted: March 7, 2005

Proofs received from author(s): May 23, 2005 